\title{
Effect of Nb on Hot Rolled High Strength Steel Sheets Produced by Thin Slab Casting and Hot Direct Rolling Process
}

\author{
Shunichi HASHIMOTO \\ CBMM ASIA CO.,LTD., 4-1-4, Akasaka, Minato-ku, Tokyo 107-0052 Japan. \\ (Received on February 14, 2003; accepted in final form on April 14, 2003)
}

\begin{abstract}
In order to meet to the demands from automobile industry such as weight reduction and safety improvement, the hot rolled high strength steel sheets have been used mainly for suspension parts. While, the steel production by thin slab casting (TSC) and hot direct rolling (HDR) process has been noticed. In this study, the characteristics of the high strength hot rolled steels produced by TSC-HDR were discussed comparing with the conventional process and concluded as follows;

(1) The effect of difference of production route on the relationship between tensile strength and elongation or tensile strength and stretch flangeability was small.

(2) Strength obtained by TSC-HDR route was higher than those of conventional production route in $\mathrm{Nb}$ bearing steel. This means Nb effectively works as a strengthening element in TSC-HDR route.

(3) The addition of $\mathrm{Nb}$ and $\mathrm{Mn}$ was effective on the improvement of tensile strength and stretch flangeabilty relationship. Especially when the stretch flangeabilty was compared in the same TS level, Nb bearing steels exhibited more than two times of the value of plain $\mathrm{C}-\mathrm{Mn}$ steel.
\end{abstract}

KEY WORDS: thin slab casting; hot direct rolling; high strength hot rolled steel sheet; elongation; stretch flangeability; Nb bearing steel.

\section{Introduction}

The automobile industry has made an effort to reduce body weight to cut down $\mathrm{CO}_{2}$ and fuel consumption. On the other hand, demand for strengthening of the body structure for safety and comfort is increasing. In order to meet to these demands, the hot rolled high strength steel sheets such as HSLA steels, Nb bearing ferrire-bainite steel ${ }^{1-4)}$ and ferrite-martensite steel ${ }^{4)}$ have been used for wheels, suspensions and bumpers. Frequently the first stage in the manufacturing of these parts is hole punching. The subsequent pressing deformation requires expansion of those holes. The hole expansion limit, i.e. stretch flangeability is recognized as one of the most important characteristics as well as elongation.

While, the steel production by thin slab casting (TSC) and hot direct rolling (HDR) process has been noticed and increasing recently. ${ }^{5)}$ However, the information about high grade steels such as high strength steel sheets or cold rolled IF steel sheets for automobile or line pipe steels produced by TSC-HDR process and their metallurgical studies have not been reported so many. The most important differences in TSC-HDR route compared with conventional production route from the metallurgical point of view are as follows;

1) no $\gamma \rightarrow \alpha$ and $\alpha \rightarrow \gamma$ transformation before hot rolling,

2) thin initial slab thickness, in other words, small total reduction,

3) low slab soaking temperature.

The main objective of the present work is to show the effect of transformation before hot rolling which is the most important difference between TSC-HDR and conventional production process on the mechanical properties such as tensile property and stretch flangeability. The tensile strength was aimed from 490 to $590 \mathrm{MPa}$ TS grade which are the most common strength grade used in these parts. In addition to it, the metallurgical views such as the effect of initial slab thickness and slab soaking temperature and the effect of $\mathrm{Nb}$ and other elements, $\mathrm{C}, \mathrm{Si}$ and $\mathrm{Mn}$, on the mechanical properties and microstructure are discussed.

\section{Experimental Procedure}

\subsection{Chemical Compositions of Steels and Processing Conditions}

Seven kinds of steels were induction melted as $40 \mathrm{~kg}$ in air. The chemical compositions of steels are shown in Table 1. Steel $\mathrm{A}$ is base steel with $0.05 \% \mathrm{C}-1.2 \% \mathrm{Mn}-0.025 \% \mathrm{Nb}$. In Steels B, C and D, higher amount of $\mathrm{Mn}, \mathrm{Si}$ and $\mathrm{Si}+\mathrm{Mn}$ are added to Steel $\mathrm{A}$, respectively. $\mathrm{Nb}$ content of Steel $\mathrm{E}$ is increased to $0.05 \%$ from Steel D. Steels F and G are plain $\mathrm{C}-\mathrm{Mn}$ steels without $\mathrm{Nb}$. Steel $\mathrm{F}$ is prepared to study the effect of $\mathrm{Nb}$, so the only $\mathrm{Nb}$ is eliminated from Steel A.

Table 1. Chemical compositions of used steels (mass \%).

\begin{tabular}{|c|c|c|c|c|c|c|c|c|c|}
\hline Steel & $\mathrm{C}$ & $\mathrm{Si}$ & $\mathrm{Mn}$ & $\mathrm{P}$ & $\mathrm{S}$ & $\mathrm{Al}$ & $\mathrm{Nb}$ & $\mathrm{N}$ & $\mathrm{O}$ \\
\hline $\mathrm{A}$ & 0.046 & 0.03 & 1.19 & 0.015 & 0.002 & 0.038 & 0.023 & 0.0067 & 0.0051 \\
\hline $\mathrm{B}$ & 0.044 & 0.04 & 1.52 & 0.016 & 0.003 & 0.045 & 0.025 & 0.0060 & 0.0070 \\
\hline $\mathrm{C}$ & 0.049 & 0.47 & 1.17 & 0.014 & 0.002 & 0.041 & 0.025 & 0.0054 & 0.0074 \\
\hline $\mathrm{D}$ & 0.049 & 0.51 & 1.45 & 0.014 & 0.002 & 0.047 & 0.025 & 0.0094 & 0.0052 \\
\hline $\mathrm{D}^{\prime}$ & 0.048 & 0.52 & 1.52 & 0.016 & 0.002 & 0.042 & 0.024 & 0.0060 & 0.0069 \\
\hline $\mathrm{E}$ & 0.047 & 0.50 & 1.53 & 0.015 & 0.002 & 0.040 & 0.049 & 0.0057 & 0.0078 \\
\hline $\mathrm{F}$ & 0.051 & 0.03 & 1.16 & 0.015 & 0.002 & 0.039 & - & 0.0059 & 0.0053 \\
\hline $\mathrm{G}$ & 0.153 & 0.03 & 1.20 & 0.015 & 0.002 & 0.042 & - & 0.0060 & 0.0047 \\
\hline
\end{tabular}




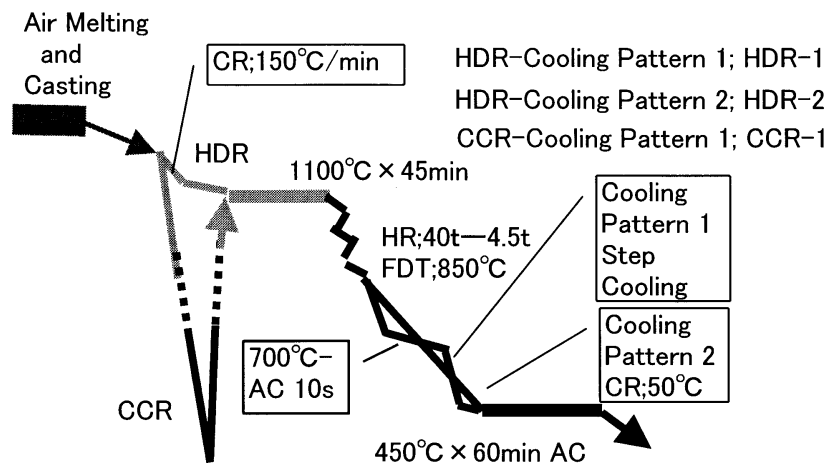

Fig. 1. Experimental procedure.

Carbon content in Steel $\mathrm{G}$ is increased to $0.15 \%$ to compare the ductility in the same strength level with $\mathrm{Nb}$ bearing steels. Steel D' is aimed the same chemical composition as Steel D.

The experimental procedure is shown in Fig. 1. Each melt, except Steel D', was poured to two or three carbon molds with $40 \mathrm{~mm}$ in thickness. One of them was cooled to room temperature to understand the result of conventional process, which was designated as CCR. Other ingots were immediately transferred to the equalization furnace kept at $1100^{\circ} \mathrm{C}$, which were designated HDR. The surface temperature before inserting to the furnace was about $1050^{\circ} \mathrm{C}$. The slabs were kept for $45 \mathrm{~min}$ in the furnace and hot rolled to $4.5 \mathrm{~mm}$ by seven passes. The aimed finish rolling temperature was $850^{\circ} \mathrm{C}$. After finish rolling, two kinds of cooling pattern were adopted. In cooling pattern 1 , the sheets were rapidly cooled to $700^{\circ} \mathrm{C}$, air cooled for $10 \mathrm{~s}$ and then rapidly cooled again to $500^{\circ} \mathrm{C}$ and then kept at $450^{\circ} \mathrm{C}$ for $1 \mathrm{~h}$ as a simulation of coiling process in the actual hot rolling mill. The cooling velocity of rapidly cooling was $70^{\circ} \mathrm{C} / \mathrm{s}$. In cooling pattern 2 , the sheets were continuously cooled at the cooling rate of $50^{\circ} \mathrm{C} / \mathrm{s}$ to $500^{\circ} \mathrm{C}$ and kept at $450^{\circ} \mathrm{C}$ as in cooling pattern 1 . The ingot which was cooled to room temperature were reheated to $1100^{\circ} \mathrm{C}$ and kept for $45 \mathrm{~min}$ followed by the same hot rolling and cooling condition as pattern 1 . Cooling pattern 1 was adopted to obtain the enough volume fraction of ferrite which brings a good elongation.

As the simple expression, the steels cooled by cooling pattern 1 or 2 after HDR is designated as HDR-1 or HDR-2 and the steels cooled by cooling pattern 1 after CCR is designated as CCR-1.

In order to study the effect of initial slab thickness, soaking temperature and coiling temperature (CT) in the conventional hot rolling process, only Steel $\mathrm{D}^{\prime}$ was cast to 120 $\mathrm{mm}$ in thickness and cooled to room temperature. The ingot was reheated to $1200^{\circ} \mathrm{C}$ and hot rolled to $40 \mathrm{~mm}$ in thickness, and after cooling to room temperature, the slabs were reheated again to 1100 or $1250^{\circ} \mathrm{C}$. The finish hot rolling and cooling condition was as same as HDR-1. In order to study the effect of reheating temperature in the steels coiled at $450^{\circ} \mathrm{C}$, only the reheating temperature of $1250^{\circ} \mathrm{C}$ was added to $1100^{\circ} \mathrm{C}$ in the above mentioned experimental condition. The effect of CT was studied by varying it from 650 to $350^{\circ} \mathrm{C}$ for the steels reheated at $1100^{\circ} \mathrm{C}$.

\subsection{Testing Procedure}

The specimens for tensile test were cut in transverse direction and machined to JIS No. 5 with $3 \mathrm{~mm}$ in thickness.

The stretch flangeability was evaluated by hole expansion ratio, $\lambda$, according to the Japan Iron and Steel Federation Standard, JFS T1001: 1996. The amount of hole expansion was obtained in a circular punch hole of $10 \mathrm{~mm}$ diameter by using the sheets machined to $3 \mathrm{~mm}$ in thickness. The burr of the test piece was set facing the die. When a conical punch with a top angle of 60 degree was forced into the hole until any one crack in the hole edge extends all through the test thickness, it was expressed as $D_{\mathrm{h}} . \lambda$ was as defined by the following equation;

$$
\lambda=\left\{\left(D_{\mathrm{h}}-D_{0}\right) / D_{0}\right\} \times 100(\%)
$$

where, $D_{0}$; Original hole diameter $\left(D_{0}=10 \mathrm{~mm}\right)$

$D_{\mathrm{h}}$; Hole diameter after rupture

The microstructure was observed by optical microscopy and Field Emmision-Scanning Electron Microscopy (FESEM).

\section{Experimental Results}

\subsection{Effect of Coiling Temperature and Soaking Tem- perature on the Mechanical Properties of the Steels Produced by Conventional Production Route}

In advance of the research on TSC-HDR process, the effects of coiling temperature and soaking temperature on the mechanical properties were examined using Steel D'.

The obtained strength and ductility are shown in Figs. 2 and 3. The data of the steel reheated to $1250^{\circ} \mathrm{C}$ were shown by star mark. With decrease in CT, Tensile Strength (TS) and Yield Strength (YS) increase. TS and YS of the steel reheated to $1250^{\circ} \mathrm{C}$ were 15 and $28 \mathrm{MPa}$ higher respectively than the steel reheated to $1100^{\circ} \mathrm{C}$. As shown in Fig. 3, total elongation (El) decreases with decrease in CT. On the contrary, hole expansion ratio, $\lambda$, increases with decrease in $\mathrm{CT}$, in spite of the decrease in $\mathrm{El}$ and increase in the strength. El and $\lambda$ of the steel reheated to $1250^{\circ} \mathrm{C}$ showed lower value than those of the steel reheated to $1100^{\circ} \mathrm{C}$.

From these results, since it is concluded that the most recommendable coiling temperature to attain high $\mathrm{El}$ and $\lambda$ with high strength is $450^{\circ} \mathrm{C}$, the coiling temperature in the experiment mentioned after was fixed as $450^{\circ} \mathrm{C}$.

\subsection{Experimental Results by TSC-HDR Process}

\subsubsection{Tensile Property}

The relationship between TS and El is shown in Fig. 4. The dotted line in this figure shows the same TS and El product of 16500 . TS and El product line of 16500 in Fig. 4 was shown to know the relationship between TS and El in various TS level. Value of 16500 is corresponded to approximately center of all of the data. The same expression was shown also in Figs. 5 and $\mathbf{6}$.

The addition of $0.025 \% \mathrm{Nb}$ to plain carbon steel, $\mathrm{F}$, brings the increase in TS of $68 \mathrm{MPa}$ along the same TSxEl product line. The addition of $\mathrm{Si}, \mathrm{Mn}$ and $\mathrm{Si}+\mathrm{Mn}$ bring the increase in TS of 42, 52 and $80 \mathrm{MPa}$ respectively, when the comparison is done in HDR-1 route. Though the addition of $\mathrm{Si}$ improves the TS-El relationship, the addition of $\mathrm{Mn}$ 


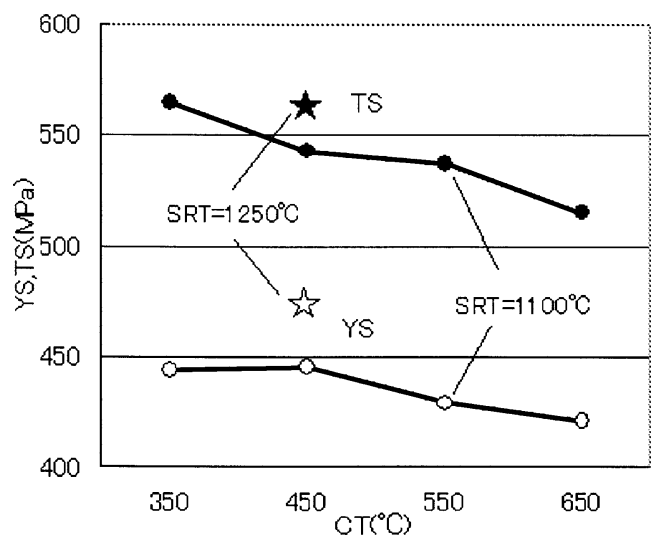

Fig. 2. Effects of coiling temperature and reheating temperature on yield strength (YS) and tensile strength (TS) of Steel $\mathrm{D}$ produced by conventional process.

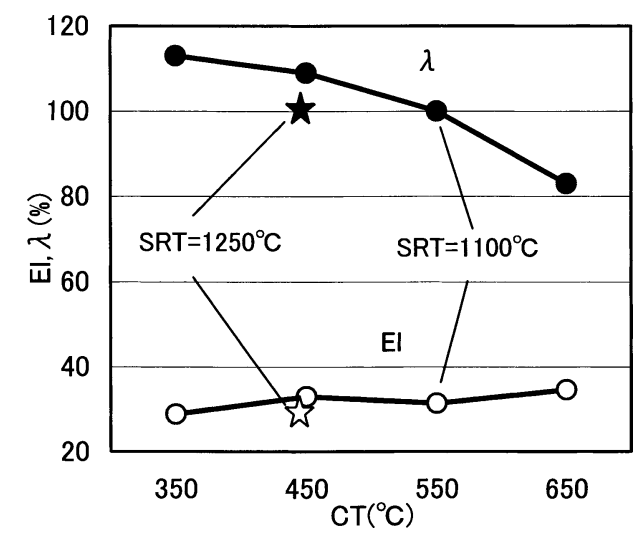

Fig. 3. Effects of coiling temperature and reheating temperature on elongation (El) and hole expansion ratio, $\lambda$, of Steel D.

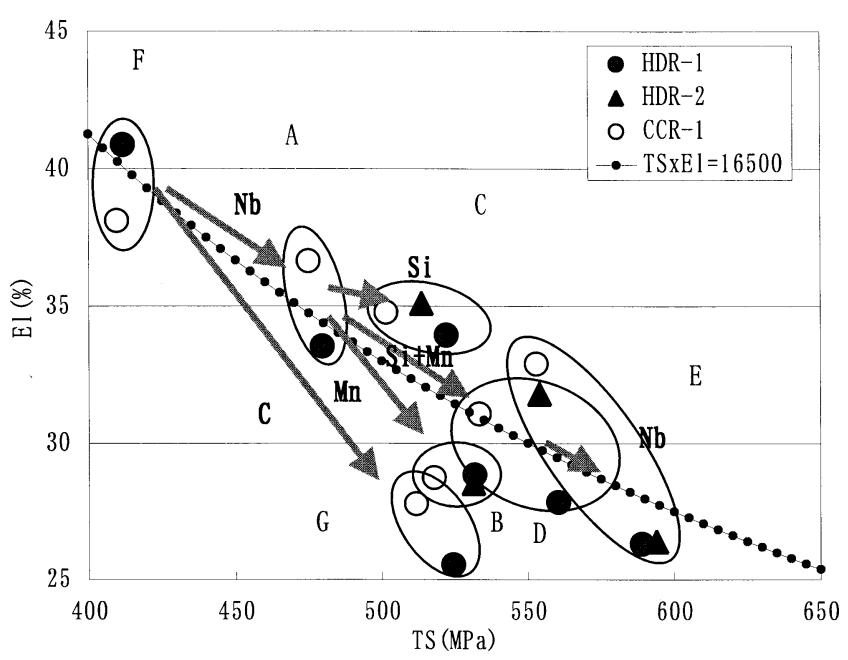

Fig. 4. Effects of production routes and alloying elements on relationship between tensile strength (TS) and elongation (El).

brings the deterioration of TS-El relationship. The addition of $\mathrm{C}, 0.1 \%$, to $0.05 \% \mathrm{C}-\mathrm{Mn}$ steel, $\mathrm{F}$, brings increase in about $100 \mathrm{MPa}$ TS but with accompanying the deterioration of El. When the El is compared in the same TS level, Si$\mathrm{Nb}$ steel, $\mathrm{C}$, shows about $8 \%$ higher value than $0.15 \% \mathrm{C}-$ $\mathrm{Mn}$ steel, G. Steel E whose $\mathrm{Nb}$ content is $0.05 \%$ shows $590 \mathrm{MPa}$ in HDR route. From these results, it is clarified that even in the HDR route, good TS and El relationship can be obtained as the conventional CCR route.

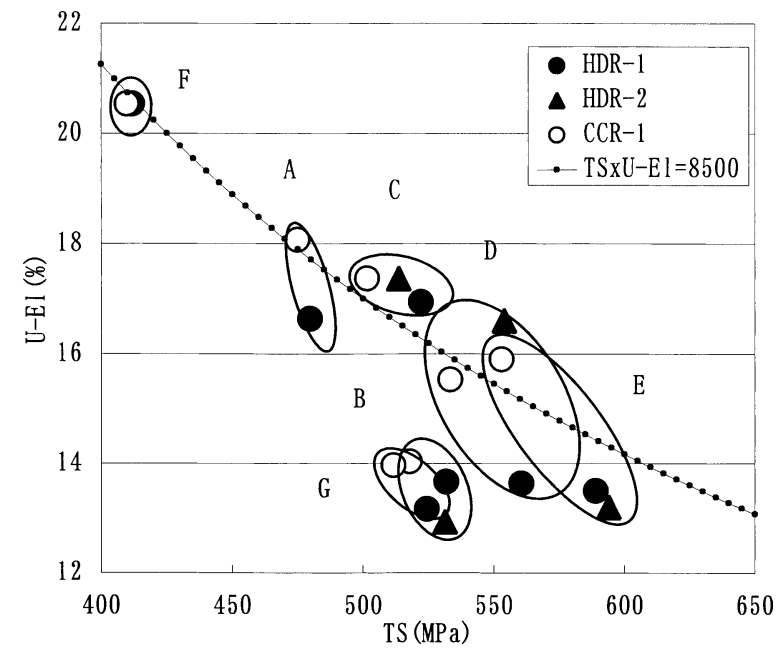

Fig. 5. Effects of production routes and alloying elements on relationship between tensile strength (TS) and uniform elongation (U-El).

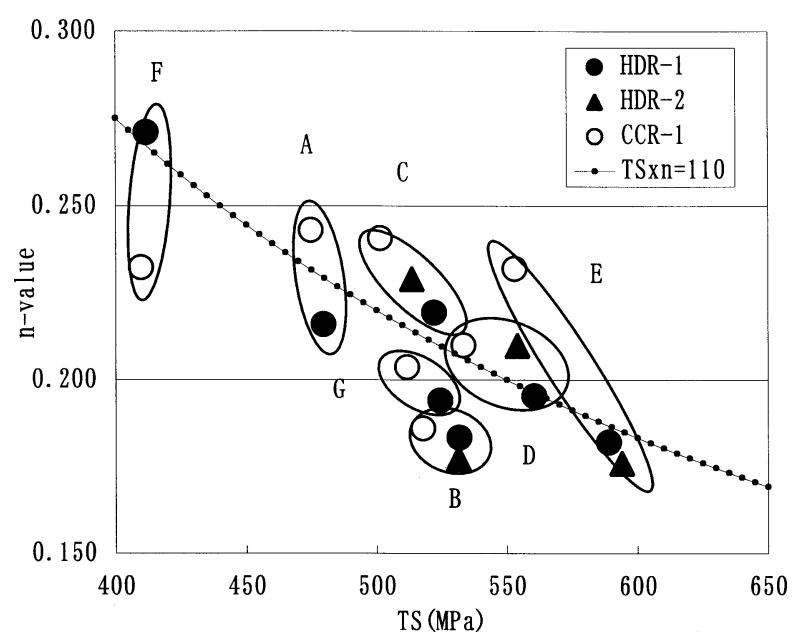

Fig. 6. Effects of production routes and alloying elements on relationship between tensile strength (TS) and $n$-value.

The relationships between TS and uniform elongation (U-El) and $n$-value are shown in Figs. 5 and 6. These figures show the same tendency as the relationship between TS and El shown in Fig. 4. The steels contain $0.5 \%$ Si show higher balance of TS and U-El, TS and $n$-value and the addition of $\mathrm{Mn}$ and $\mathrm{C}$ exhibited the deterioration of these balance.

Figure 7 shows the relationship between TS and YS. All of the $\mathrm{Nb}$ bearing steels are locating on the line of Yield Ratio $(\mathrm{YR})=0.85$ and $\mathrm{C}-\mathrm{Mn}$ steels are on the line of $\mathrm{YR}=$ 0.75 .

\subsection{Stretch Flangeability}

The relationship between TS and hole expansion ratio, $\lambda$, is shown in Fig. 8. The dotted line in this figure shows the same TS and $\lambda$ product of 46000 . Steels B and E, which contain high $\mathrm{Mn}$ and high $\mathrm{Nb}$ respectively, show the highest TS $-\lambda$ balance. Si added $\mathrm{Nb}$ bearing steels $\mathrm{C}$ and $\mathrm{D}$ show next high TS- $\lambda$ relationship. Though TS-El balance of Steel B was low among $\mathrm{Nb}$ bearing steels, TS- $\lambda$ balance of it was the best. When the $\lambda$ is compared in the same TS level, $\mathrm{Mn}-\mathrm{Nb}$ or $\mathrm{Si}-\mathrm{Nb}$ steels show higher than twice of those of $0.15 \% \mathrm{C}-\mathrm{Mn}$ steel, $\mathrm{G}$. 


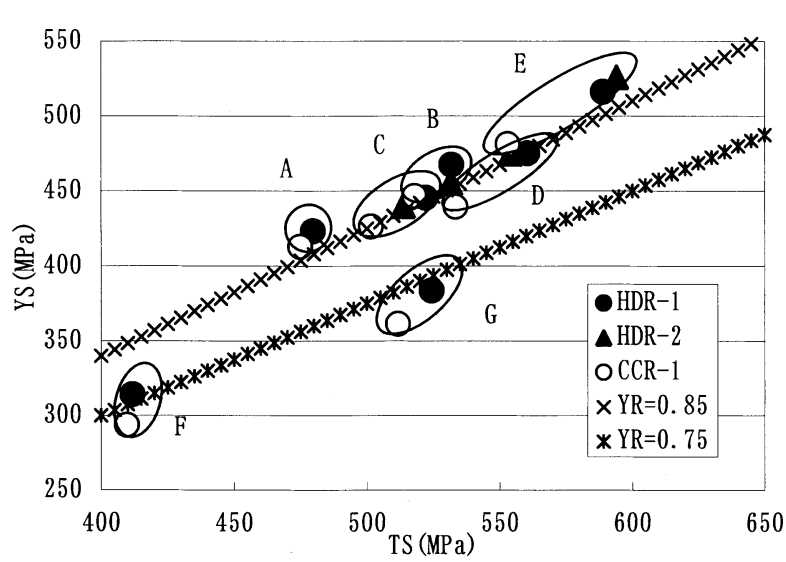

Fig. 7. Effects of production routes and alloying elements on relationship between tensile strength (TS) and yield strength (YS)

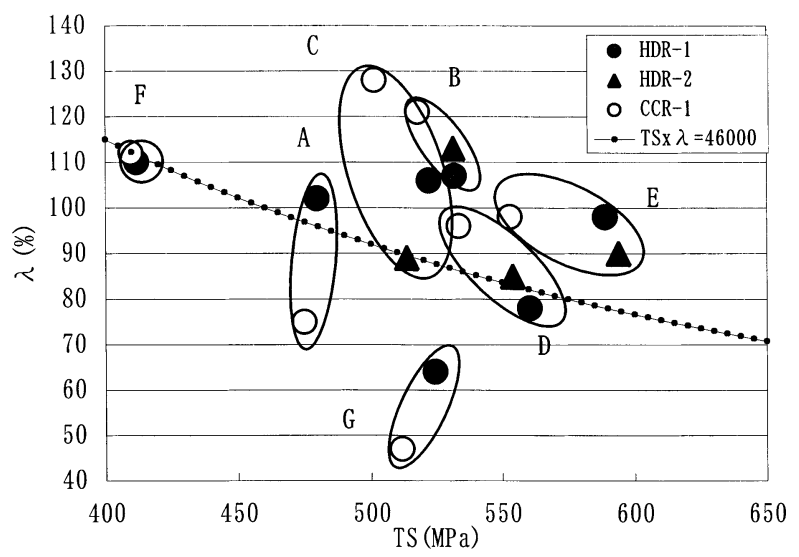

Fig. 8. Effects of production routes and alloying elements on relationship between tensile strength (TS) and hole expansion ratio, $\lambda$.
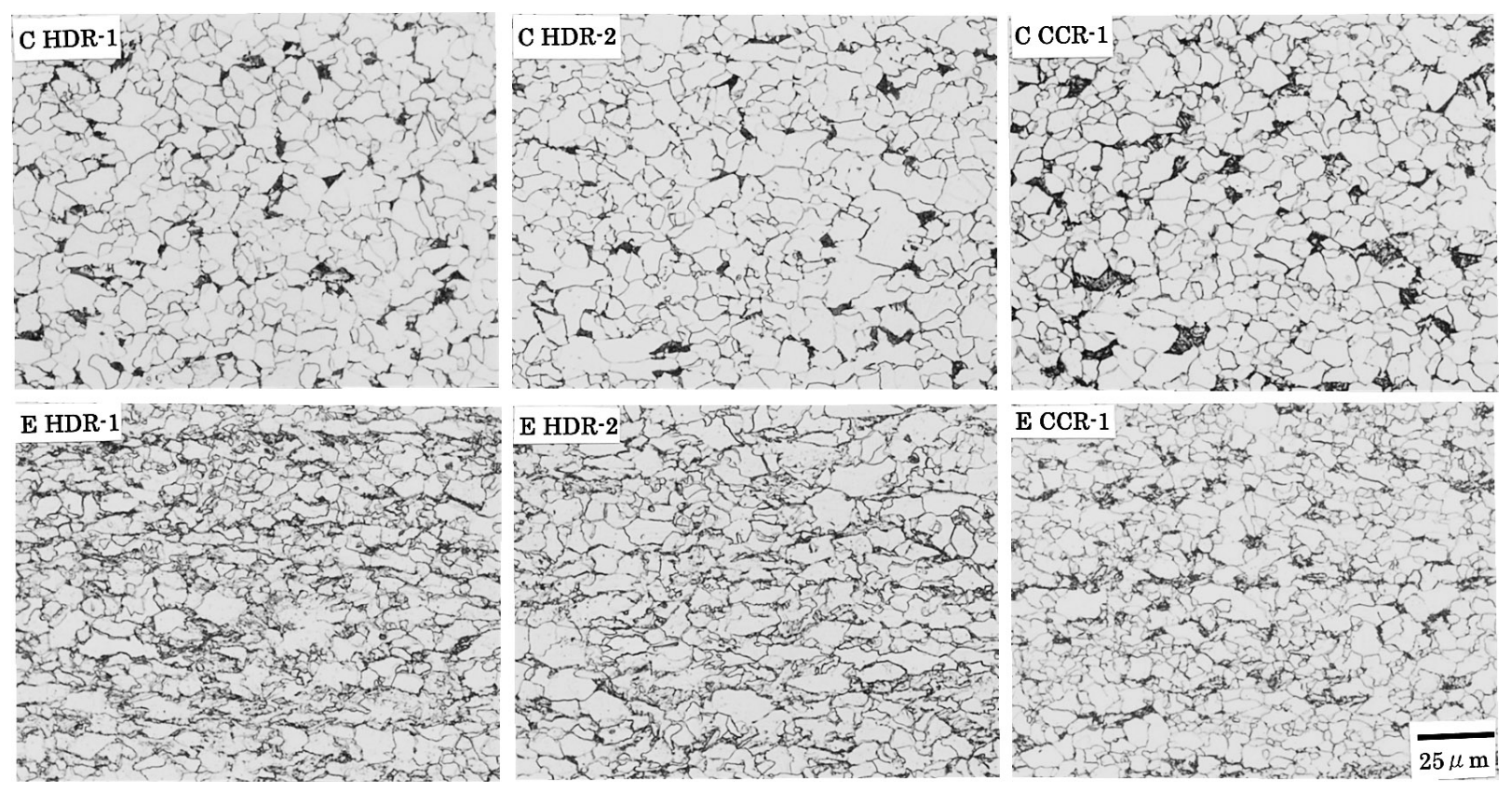

Fig. 9. Effects of production routes, HDR-1, HDR-2 and CCR-1, on optical micrographs of Steels C and E.

\subsection{Microstructure}

The effect of production routes, HDR-1, HDR-2 and CCR-1, on the optical microstructures of Steels C and E etched by 3\% Nital are shown in Fig. 9. All of the steels show nearly same grain size and the same volume fraction of ferrite and second phase, that is, the difference in microstructure among the three kinds of production routes is small. The same tendency is observed except low carbon steel, F. Ferrite grains of Steel C showed equiaxed, but those of Steel E showed elongated and irregular grain boundary.

The nature of second phase was observed by FE-SEM. Figure 10 shows the micrographs of Steels $C$ and E produced by HDR-1 and CCR-1. The second phase of these steels was bainite. However only HDR-1 of Steel C exhibited pearlite and degenerated pearlite. Generally speaking, all of the $\mathrm{Nb}$ containing steels showed the mixture of bainte and degenerated pearlite as second phase.

The effects of production routes and alloying elements on the ferrite grain size are shown in Fig. 11. The grain size was about $10 \mu \mathrm{m}$ except $\mathrm{Nb}$-free low carbon steel, F. In spite of the difference in the production routes, Steels A, B, $\mathrm{E}$ and $\mathrm{G}$ showed nearly same grain size. On the other hand, the Steels $\mathrm{C}, \mathrm{D}$ and $\mathrm{F}$ showed the difference in grain size with the difference in production rotes, but tendency with them was not uniform. In Steels C and D, CCR showed larger grain size than HDR, and cooling pattern 2 showed smaller grain size than cooling pattern 1 . On the other hand, in Steel F, HDR showed larger grains than CCR.

Judging from these results, the microstructure of these steels was not affected by the difference of production route, HDR and CCR. However $\mathrm{Nb}$ free low $\mathrm{C}$ steel $\mathrm{F}$ showed very large grain size in HDR. When the comparison between cooling pattern in HDR is made, the steels continuously cooled showed smaller grain size than the step cooled steels.

\section{Discussion}

As expressed in the introduction, the metallurgical differences between TSC-HDR and conventional process are in no $\gamma \rightarrow \alpha$ and $\alpha \rightarrow \gamma$ transformations before hot rolling, thin 

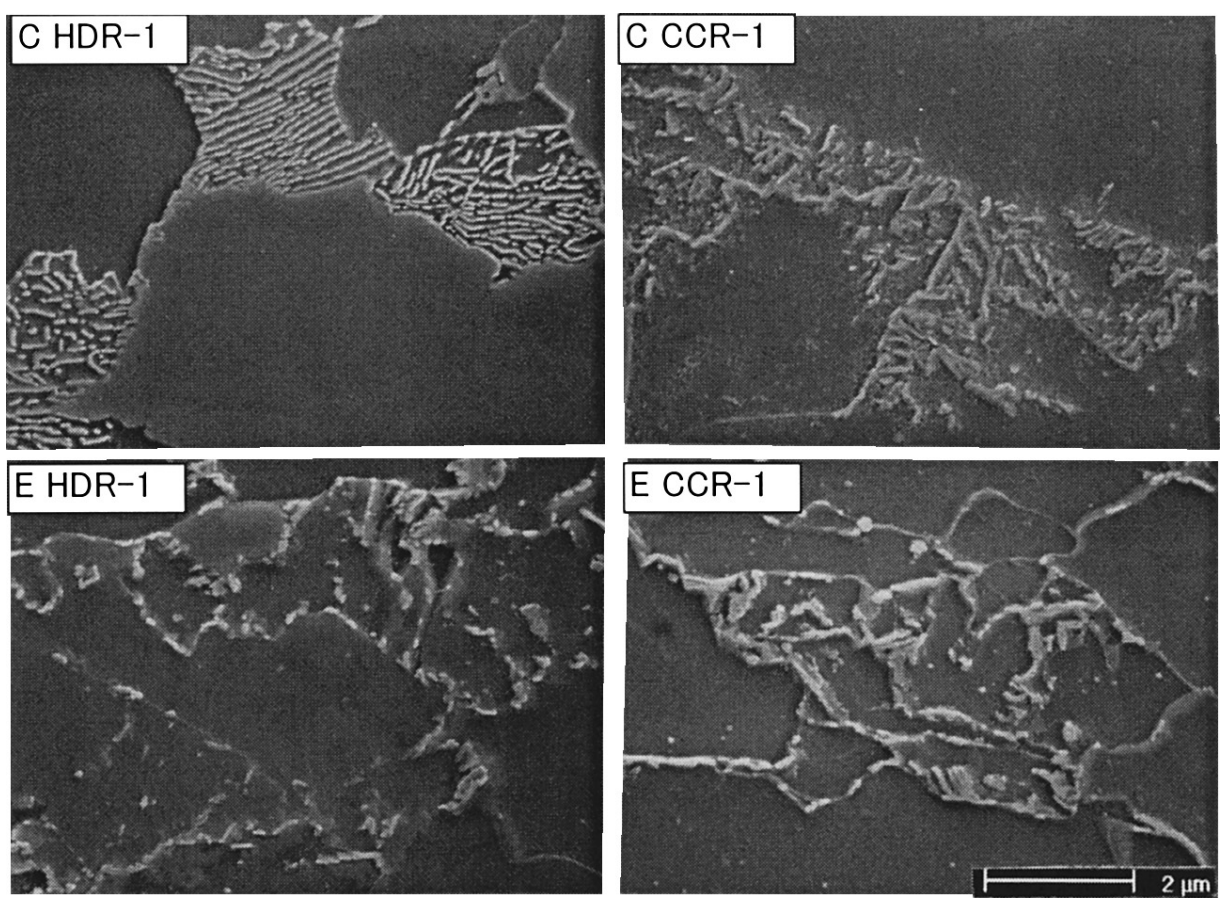

Fig. 10. Effects of production routes, HDR-1 and CCR-1, on the scanning electron micrographs of Steels $\mathrm{C}$ and $\mathrm{E}$.

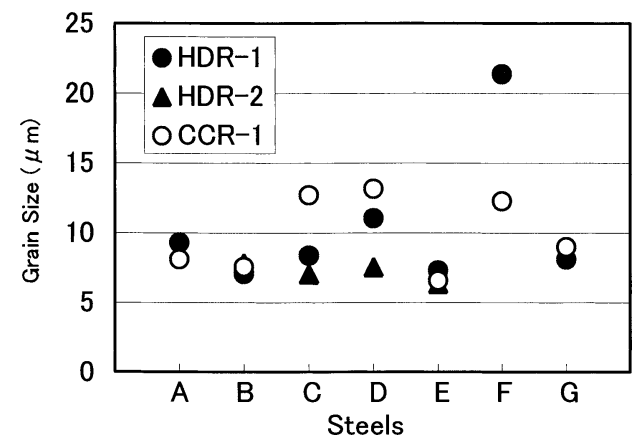

Fig. 11. Effects of production routes and alloying elements on the ferrite grain size.

initial slab thickness and low slab soaking temperature. The effects of these differences on the mechanical properties are discussed.

\subsection{Tensile Strength}

The relationships between TS and El, U-El, $n$-value and YR were hardly affected by the production routes, HDR-1, HDR-2 and CCR-1. However, TS of the Nb bearing steels produced by HDR route was higher than the steel sheets produced by CCR route. Figure 12 shows the effect of $\mathrm{Nb}$ content and production process on TS. In 0.025 and $0.05 \%$ $\mathrm{Nb}$ containing steels, $\mathrm{D}$ and $\mathrm{E}$, the difference in TS between HDR and CCR was 27 and $35 \mathrm{MPa}$ respectively. The difference of TS of reheating temperature between 1250 and $1100^{\circ} \mathrm{C}$ in the conventional process of Steel $\mathrm{D}^{\prime}$, which has nearly same chemical composition as Steel D, was $15 \mathrm{MPa}$. The absolute TS of D-HDR-1 and D'-1250 which is reheated at $1250^{\circ} \mathrm{C}$ in the conventional process is nearly same as $560 \mathrm{MPa}$. On the other hand, no difference of TS was observed in C-Mn steel, F. It is well known that the strength increases with grain refinement and increase in the precipitation hardening which relates with solute $\mathrm{Nb}$ content before hot rolling. ${ }^{6-8)}$ In this study, since the difference of grain size in HDR and CCR routes is small, the reason for

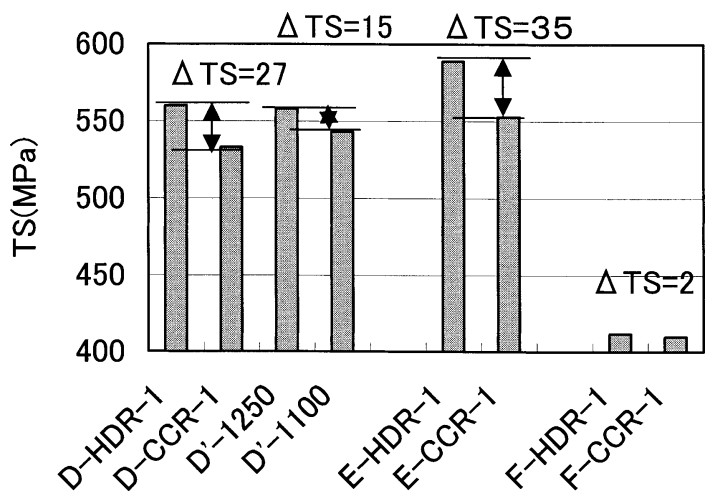

Fig. 12. Effects of production routes and $\mathrm{Nb}$ contents on tensile strength.

higher strength in HDR route can not be attributed to the difference of the grain size. Papers ${ }^{9-14)}$ referring to direct hot rolling process or hot charge rolling process showed the same tendency and explained it as the difference in solute $\mathrm{Nb}$ content calculated by solubility product of $\mathrm{Nb}(\mathrm{C}, \mathrm{N})$ at the reheating temperature. Therefore the higher tensile strength in HDR of present study is explained as solute $\mathrm{Nb}$ before hot rolling is higher than those of CCR route. It is reported that the nose of $\mathrm{Nb}(\mathrm{C}, \mathrm{N})$ precipitation time-temperature diagram in austenite region is around $950^{\circ} \mathrm{C}^{9,13)}$ and the precipitation velocity of hot charged process is about two times of cold charged process. ${ }^{13)}$ From these results obtained by the previous works, the relationship between precipitation diagram and process condition in this experiment is schematically drawn as in Fig. 13. The reason why precipitation is retarded in HDR is thought to be come from the low precipitation site on the austenite grain boundary due to their large grain size.

In the conventional process, in order to use $\mathrm{Nb}$ effectively for obtaining precipitation hardening, it is necessary to increase the reheating temperature to solve $\mathrm{Nb}$ as high as $1250^{\circ} \mathrm{C}$. However, it is possible to utilize $\mathrm{Nb}$ effectively 


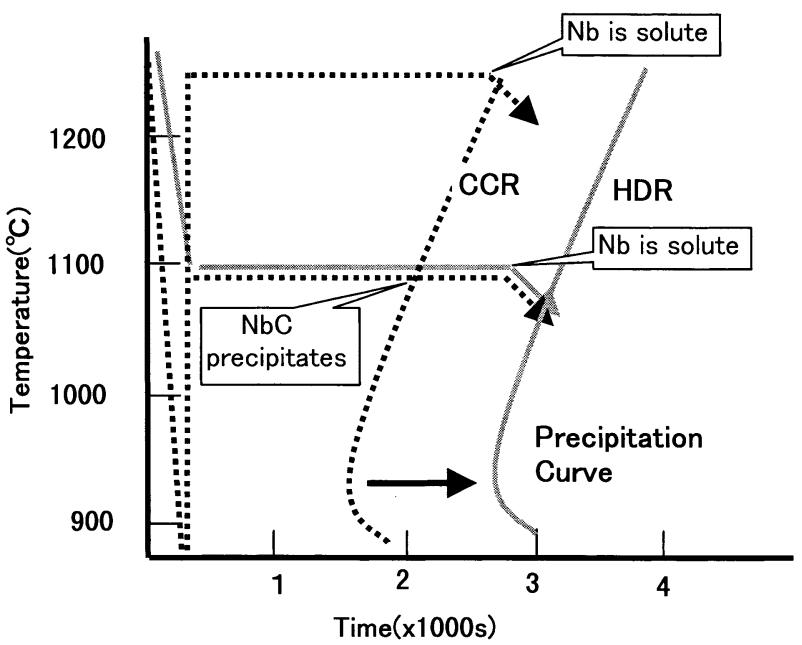

Fig. 13. Schematic illustration showing relationship between precipitation curve of $\mathrm{NbC}$ and heat cycles in each production route.

even in the low equalization temperature by adopting HDR process.

\subsection{Stretch Flangeability}

It is well known that the stretch flangeability is affected by sulfur content which relates with the size and volume fraction of non-metallic inclusion ${ }^{15,16)}$ and carbon content which relates with the volume fraction of pearlite or cementite. ${ }^{15,17,18)}$ In addition to them, the importance of microstructure $^{19,20)}$ and grain size ${ }^{21)}$ have been also pointed out. Though these results were obtained by the conventional production route, the metallurgical background on stretch flangeability must be common in both of the TSC-HDR and CCR routes.

In this experiment, since sulfur content is nearly same in all of the steels, the effect of non-metallic inclusions on the stretch flangeability is negligible. The reason why high carbon containing steel, $\mathrm{G}$, shows lower value than other $\mathrm{Nb}$ bearing low carbon steels in the same tensile strength level is thought to be come from the difference of the volume fraction of second phase as pointed out by many researchers. $^{15,17-19)}$

Steels $\mathrm{B}$ and $\mathrm{E}$ which contain high $\mathrm{Mn}$ and $\mathrm{Nb}$ exhibited high TS and $\lambda$ balance despite of the lower TS and El compared with other $\mathrm{Nb}$ bearing steels. As shown in Fig. 10. the second phase of Steel E was mainly bainite. High Mn steel, $\mathrm{B}$, also exhibited bainite as a second phase. On the other hand, some pearlites were mixed in Steel C. The increase in $\mathrm{Mn}$ and $\mathrm{Nb}$ suppresses the pearlite transformation during cooling and coiling process. Therefore pearlite or degenerated pearlite observed in other steels was eliminated in these steels. As discussed by Hashimoto et al. ${ }^{1-3)}$ when the second phase is controlled to bainite, TS- $\lambda$ balance is extremely improved compared with pearlite or martensite. The excellent stretch flangeability in these steels is explained from this point of view.

Including the stretch flangeability, the relationship between strength and ductility was not so affected by the difference of production process, HDR and CCR.

\section{Conclusions}

The effects of production routes and alloying elements on the mechanical properties such as tensile property and stretch flangeability of hot rolled high strength steel sheets were investigated. Main results were summarized as follows.

(1) The effect of difference of production route, HDR and CCR after TSC, on the relationship between tensile strength and elongation or tensile strength and stretch flangeability was small. These results must be brought by that microstructure was hardly affected by the difference of the production route.

(2) However strength obtained by TSC-HDR route was higher than conventional production route in $\mathrm{Nb}$ bearing steel. This means $\mathrm{Nb}$ effectively works as a strengthening element in TSC-HDR route. This is thought to be brought by the enough solid solute $\mathrm{Nb}$ even at the low equalization temperature.

(3) The addition of $\mathrm{Nb}$ and $\mathrm{Mn}$ was effective on the improvement of tensile strength and stretch flangeabilty relationship. Especially when the stretch flangeabilty was compared in the same $\mathrm{TS}$ level, $\mathrm{Nb}$ bearing steels exhibited more than two times of the value of plain C-Mn steel.

(4) The addition of Si brought good tensile strength and elongation relationship, and the addition of $\mathrm{Mn}$ and $\mathrm{Nb}$ brought good tensile strength and stretch flangeability relationship.

\section{Acknowledgements}

The author would like to thank Kobelco Research Institute, Inc. for their help in executing the whole experiment.

\section{REFERENCES}

1) M. Sudo, S. Hashimoto and S. Kambe: Trans Iron Steel Inst. Jpn., 23 (1983), 303

2) S. Hashimoto, S. Kambe, M. Sudo and Y. Tsugami: SAE Technical Paper Series, 820283 (1982)

3) S. Hashimoto, M. Sudo, T. Hosada and Z. Shibata: Proc. of HSLA Steels '85, ASM, Ohio, (1985), 8520-018.

4) S. Hashimoto: J. Soc. Automot. Eng. Jpn., 54 (2000), 39

5) Proc. of TSCR' 2002, CSM, Beijing, (2002).

6) K. Sato and M. Suehiro: Tetsu-to-Hagané, 77 (1991), 675.

7) K. Sato and M. Suehiro: Tetsu-to-Hagané, 77 (1991), 1328.

8) S. Nomura, N. Komatsubara and K. Kunishige: Tetsu-to-Hagané, 79 (1993), 83.

9) M. Oda, H. Kubo, O. Akisue and K. Nakazawa: Tetsu-to-Hagané, 74 (1988), 2323.

10) Y. Hashimoto: Tetsu-to-Hagané, 72 (1986), 2263.

11) Y. Kamada, T. Hashimoto and S. Watanabe: Tetsu-to-Hagané, 74 (1988), 1446

12) M. Murata, K. Nishioka and H. Tamehiro: Tetsu-to-Hagané, 74 (1988), 1454.

13) G. Matsumura, S. Sanagi, Y. Onoe and H. Katoh: Tetsu-to-Hagané, 74 (1988), 1470.

14) I. Tsukatani, T. Yakushiji, M. Katsumata, K. Hosomi and M. Sudo: Tetsu-to-Hagané, 74 (1988), 1493.

15) H. Kobayashi: SAE Technical Paper Series, 910513 (1991).

16) K. Misonoh, T. Fujii, R. Fukumoto and A. Nakajima: Tetsu-toHagané, 68 (1982), 147.

17) T. Yamaguchi and H. Taniguchi: NKK Tech. Rep., 45 (1969), 24.

18) N. Matsuzu, A. Itami and K. Koyama: SAE Technical Paper Series, 910513 (1991)

19) S. Hashimoto, M. Sudo, K. Mimura and T. Hosada: Trans Iron Steel Inst. Jpn., 26 (1986), 985.

20) T. Kashima and S. Hashimoto: Tetsu-to Hagané, 87 (2001), 146

21) H. Yasuhara, K. Okuda, A. Tosaka and O. Furukimi: CAMP-ISIJ, 12 (1999), 1219. 